UDC 75(497.5)“1914/1925“ Šumanović S.

Страхиња Л. Радаковић

Универзитет у Новом Саду

докторанд

radakovic.strahinje@gmail.com
Оригиналан научни рад

примљено: 12. април 2012

прихваћено: 1. октобар 2012

\title{
ЗАГРЕБАЧКИ ПЕРИОД У СЛИКАРСТВУ САВЕ ШУМАНОВИЋА ОД 1914. ДО 1925. ГОДИНЕ*
}

Сажетак: Рад се бави историјским контекстом сликарства Саве Шумановића током његовог боравка у Загребу, тадашњом загребачком културном сценом, носиоцима авангардних тенденција у уметности, чију је подршку имао Шумановић као и отпором који је пружан новим уметничким струјањима. Рад говори и о Шумановићевој борби за модерне идеје конструктивног сликарства. Бави се такође важним моментима Шумановићевог личног живота, односом према родитељима и Антонији Кошчевић, као и кругом његових блиских пријатеља. Кроз рад се провлачи и сложено питање српско-хрватских односа.

Кључне речи: Сава Шумановић, загребачки период, загребачка културна сцена, конструктивно сликарство, Антонија Кошчевић, српско-хрватски односи.

Сава Шумановић је стварао у периоду између два светска рата у некадашњој Југославији и извесно време у Француској. Критичари јесу и нису разумели то што ради, хвалили су и нападали његов рад, ипак нико није остао равнодушан. Данас можемо рећи да је својим сликама и животом обележио своје доба. Сава Шумановић је рођен 1896. године у Винковцима, пошто му је отац тамо службовао. Мајка Персида и отац Мулутин рођени су у Шиду, након што се отац 1900. године превремено пензионисао, вратили су се у Шид. Обоје потичу из богатих грађанских породица. Прва четири разреда основне школе похађао је у Шиду. ${ }^{1}$ У основној школи је био тих, миран и повучен, а са људима није много контактирао. Дружио се највише са три школска друга, Обрадом Нешковићем, Ранком Ракићем и Николом Тубићем. НиколаТубић је једном приликом видео Саву Шумановића како слика изван Шида, на узвишењу званом Бељњача. Посматрао је Шид и сликао са тог места Русинску цркву и околину. Његов таленат није остао

\footnotetext{
* Рад је фрагмент магистарског рада Историјски контекст сликарства Саве Шумановића одбрањеног 20.04.2010. године на Филозофском факултету у Новом Саду пред комисијом у саставу: др Александар Касаш, др Љубодраг Димић и др Биљана Шимуновић-Бешлин.

${ }^{1}$ Љубица Миљковић, Сава Шумановић. Препуштање пасији, Београд 2007, 15-19.
} 
незапажен код другова, који су му се дивили. Никола Тубић је касније о сликару причао својој ћерки Цветанки. У четвртом разреду основне школе, нацртао је оловком портрет свог учитеља Стевана Пајића. ${ }^{2}$

Шумановић је од 1906. до 1914. године похађао гимназију у Земуну, тзв. реалку. Путем писама је редовно обавештавао родитеље о свему што му се дешавало, пише им да је кажњен због пушења али и због тога што је рекао девојчицама да су ћурке. У писмима из виших разреда гимназије, може се уочити његова жеља за куповином књига, пошто тражи од родитеља новац за куповину. Распуст је сваке године проводио у Грацу, код стричевог пријатеља, протестантског пастора Гетварта, што му је помогло да добро научи немачки језик.

Гимназијски наставник цртања Исидор Јунг утицао је на Шумановићево озбиљније интересовање за сликарство. Похађао је и његов приватни курс сликарства, где се упознаје са импресионистичким ${ }^{3}$ сликањем, пре свега Сезана и Ван Гога. ${ }^{4}$ Подстанарску собу у Земуну делио је са Бориславом Богдановићем из Руме, будућим сликарем и пијанистом. ${ }^{5}$ Шумановић је у Земуну скицирао кровове и ограде, чамце на Дунаву, корпе јабука и грожђа, што су му родитељи доносили из Шида. Воденим бојама и техником уља сликао је пејзаже, на којима је уочљив покушај слободнијег интерпретирања приказаних мотива. Занимљиво је да је наглашавао како је у то време много научио од свог школског друга Славка Воркапића. ${ }^{6}$

Сава Шумановић је матурирао у Земунској гимназији 5. јуна 1914. године и тако као осамнаестогодишњак напустио Земун. Вратио се у Шид и пружио отпор жељи родитеља да почне студирати право. Отац се противио његовој жељи да постане сликар, сматрајући то готово нечим неприличним, претио је да ће се одрећи сина. Мајка је убедила оца да попусти, објашњавајући му да им син неће бити обичан сликар већ да ће уписати школу и постати професор. Почео је Први светски рат и отац Милутин је у својству таоца био задржан у шидском затвору. Несигурност пограничног подручја утицала је на Милутина да пошаље сина у Загреб, код свог рођеног брата Светислава Шумановића. Тако је Шумановић отишао у Загреб да полаже пријемни испит на Привременој Вишој школи за умјетност и умјетнички обрт. ${ }^{7}$ Доласком у Загреб, настанио се код свог стрица Светислава Шумановића, на углу Зрињевца и Прашке улице. Светислав је био веома утицајна личност, био је доктор правних наука, бавио се адвокатуром и политиком. Био је посланик, руководилац унутрашњег одела Земаљске владе,

\footnotetext{
${ }^{2}$ По сведочењу Цветанке Тубић.

${ }^{3}$ Импресионизам- уметнички правац настао седамдесетих година 19. века у Француској. Сликари импресионисти настоје да репродукују тренутне утиске и расположења, промене боја у светлу и сенци. Реч импресија значи утисак, доживљај, субјективна оцена.

${ }^{4}$ Сава Шумановић, Католог изложбе 1939, Нови универзитет, Београд 1939, 8-9.

${ }^{5}$ Борислав Богдановић је отац познатог режисера Питера Богдановића.

${ }^{6}$ Славко Воркапић (Добринци, 1894- Мијар 1976) касније се мање бавио сликарством али је стекао славу на пољу филмске уметности у САД.

${ }^{7}$ У Београду се стицало само основно ликовно образовање у Уметничко-занатској школи која је од 1919. г. прерасла у Уметничку школу. У Загребу је, од 1907. г. основана Привремена Виша школа за умјетност и умјетни обрт.
} 
подбан, председник Управног одбор Српске кредитне банке, а касније је постао и члан Сабора Независне Државе Хрватске. ${ }^{8}$ Сава Шумановић је био веома близак са Светиславовом ћерком Кристином, касније удатом за др Ђурицу Ђорђевића. Криста је била велики љубитељ уметности а показаће се и као велики мецена уметника. Била је један од оснивача Удружења пријатеља уметности „Цвијета Зузорић“ а касније и пријатељица будућег председника Југославије, Јосипа Броза Тита. ${ }^{9}$ Такво окружење је сигурно утицало да Шумановић веома млад постане свестан историјских прилика и политичког окружења. Педагошки реноме наставника у уметничкој школи коју је похађао, био је веома висок. Прву годину провео је у класи Отона Ивековића, а те године упознаје и пријатеље: Штајнера, Тиљка, Трепшеа, Сабљака и друге. Посебно је био близак са Миланом Штајнером, па му је његова прерана смрт изузетно тешко пала. Шумановић је отишао од стрица, изнајмио стан и атеље и наставио озбиљно да ради. Прешао је у класу Клемента Црнчића, кога је веома ценио и до краја остао у његовој класи. Говорио је „Код њега сам учио цртати по узорима Микеланђела и Дирера, а сликати по Рубенсу, Рембранду, а сам сам радио изван школе по Манеу, Сезану и Монеу.“10

Далеко од фронтова и оружја, хрватски уметници су се залагали за начела модерне, исто као и они српски који су их, вративши се са европских академија, спроводили у дело и истовремено, као добровољци у рату, бранили отаџбину. Период од 1895. до 1914. године назван је у историји хрватске књижевности „Модерном“. То су била нова културна дешавања која су тада под утицајем омладине захватила национални живот, од политике и науке до ликовних уметности. Представници модерне били су књижевници Антун Густав Матош, Владимир Назор, Мирослав Крлежа, сликари Јосип Рачић, Мирослав Краљевић, вајар Иван Мештровић и др. ${ }^{11}$ Тадашње политичке прилике Балкана су узавреле. Хрватска се налазила у саставу Аустроугарске, међутим у то време је југословенска национална револуционарна омладина била у свом пуном полету. На свим југословенским странама, у свим већим центрима аустроугарске државе осећало се живо кретање југословенске омладине која је била борбена и некомпромисна у својим тежњама и циљевима. И Срби и Хрвати и Словенци постали су у омладинским редовима једна душа, са заједничким смером. Покретани су бројни листови и часописи, осниване су групе и организације са југословенском оријентацијом. Након Славка Цуваја, за комесара је постављен Иван Скерлец (19131917) проглашен за бана. За његова бановања букнуо је после сарајевског атентата 28. јуна 1914. године, светски рат, који је за бановања Антуна Михаловића (19171918) донео Хрватској 29. октобра 1918. године ослобођење, па затим народно

\footnotetext{
${ }^{8}$ Жељко Фајфрић, Шид од оснивања до 1914. године, Шид 2003, 250-253.

${ }^{9}$ После Другог светског рата била је запослена у Одељењу за културне везе са иностранством при Министарству за науку и културу. Народном музеју у Београду даровала је „Белу вазу“, неколико уља на платну као и дела наших познатих сликара, Мила Милуновића, Миће Поповића, Ивана Табаковића и Пеђе Милосављевића. Љ.Миљковић, Сава Шумановић. Препуштање пасији, Београд 2007, 20.

${ }^{10}$ С. Шумановић, Каталог изложбе 1939, Нови универзитет, Београд 1939, 9.

${ }^{11}$ Zvane Črnja, Kulturna historija Hrvatske. ideje-ličnosti-dela, Zagreb 1965, 521-549.
} 
уједињење у Краљевину Срба, Хрвата и Словенаца 1. децембра 1918. године. ${ }^{12}$ Сава Шумановић је на крају школске године из свих предмета оцењен као веома добар. Био је радостан што је на више изложби имао прилику да прикаже своје слике. Крајем 1918. и током 1919. године створио је свој први циклус „Пасија“ Циклус чине радови „Милосрдни Самаританац“, „Скидање с крста“, „Голгота“, „Плач Јеремијин“, „На зидовима Јерусалимским“, „Свети Себастијан“, „Свети Ђорђе“, „Последња вечера“, „Христос на гори Маслиновој“ и други радови сличне тематике. Теме тих радова су религиозне, али оне су ипак одраз његовог личног интерпретирања новозаветних догађаја и наговештаја најинтимнијих младалачких размишљања. На овакве теме могла су да га подстакну страдања људи током Првог светског рата, борба добра и зла, али и суочавање са својом личном пасијом тј. сликарством. Слике су наишле на позитиван одјек критике, што му је импоновало и прилично га охрабрило. Занимљиво је да је његово дело на изложби југословенских уметника у Паризу, било први представник новостворене државе Срба, Хрвата и Словенаца.

У време Шумановићевог првог боравка у Загребу (1914-1920), у хрватској уметности изузетно је јак утицај симболизма и сецесије. Сецесија је највише била промовисана преко уметничке групе „Медулић“ на челу са Мештровићем, већ светски признатим вајаром и сликарима: Кризманом, Рачким, Бабићем, Ванком. Били су заступници патетичног фигуративног монументализма и декоративне стилизације. Постојала је и струја која је пропагирала стил „Минхенског круга“, ${ }^{13}$ Рачића, Бецића и Краљевића. Од њих су се симболистичке и сецесионистичке енергије кретале ка експресионизму. ${ }^{14}$ Сви ти утицаји су се често преплитали и претапали један у други, али је чињеница да су оставили трага и на сликарству Саве Шумановића у том периоду. Шумановићев школски период завршава се у јулу 1918. године, оцена о њему је гласила „Господин Сава Шумановић врло даровит, особито марљив и савјестан у раду. Получио је изванредне успјехе у фигуралном рисању и сликању. Упутио се у све технике графичких струка. Као кандидат за учитељство рисања бит ће уз стечену вјештину особито добар, савјестан учитељ“15

\footnotetext{
12 Проглашењем рата, ванредног стања у Хрватској и Славонији, као и у осталој Хабзбуршкој монархији, пресечен је цео политички живот, док је у јавном животу постојала одлучна воља војничких власти. Одмах су истакнути политичари и присталице хрватско-српске коалиције делом ухапшени, делом интернирани, браћа Прибићевић, Срђан Будисављевић, Иван Лорковић и др. Жариште хрватске политичке активности преноси се и у иностранство,а главни актери су Иван Мештровић, Франо Супило, Анте Трумбић и др. У Хрватској и Славонији трајаће до априла 1915. прикривена борба између војне и цивилне власти, у Загребу војна власт није дошла никада до изражаја . На првом ратном заседању хрватски сабор открива ратне циљеве хрватске политике, тражи се уједињење и самоуправа Јужних Словена. Ferdo Šišić, Pregled povijesti hrvatskoga naroda, Zagreb 1962, 468-469. Josip Horvat, Politička povijest Hrvatske, Zagreb 1936, 436-502.

${ }^{13}$ Минхенски круг- група уметника експресиониста у Немачкој 1905. г. оснива у Дрездену групу „Мост“ а нешто касније у Минхену групу „Плави јахач“. Више их повезује схватање живота него сликарски стил и формална решења.

14 Експресионизам- правац у уметности који инсистира на изражавању субјективних расположења и личних доживљаја без одређених правила о спољашњој форми и без обзира на естетску допадљивост.

${ }^{15}$ Dimitrije Bašičević, Sava Šumanović. Život i delo, Novi Sad 1997, 11.
} 
Шумановић је ипак желео само да буде сликар тако да није много марио за професорски испит а није желео ни да плаћа приватне часове за предмет дескриптивне геометрије, који није учио а који се на испиту полагао. Нису му дозволили да полаже испит из историје уметности и опште историје и географије. Преселио се из атељеа у Босанској улици у атеље у Шубићевој улици број 8, који му је уступио вајар Јун. Делио га је једно време са вајарком Милом Вод, која је касније говорила о њему, како се волео смејати у том периоду и како је изгледао „Хрзао је као ждребе и показивао два реда здравих, јаких, бијелих зуби. Тако је хрзао, да је све око себе натерао на смијех. Коса му је била црна и сјајна с увојцима на тјемену, очи тамне. Био је доста висок и чврсто грађен, а начин како је давао себе чинио га је старијим него је уистину био по годинама, али ноге су му биле искварене у кољенима а табани равни, посве равни, да је каткада управо тешко ходао. То га је спасило да није у Првом свјетском рату морао ићи у рат за Аустрију.“16

Шумановић се почетком свог школовања у Загребу, упознао са Антонијом Кошчевић, која се дружила са Милом Вод. Са Антонијом се упознао још 1914. године у школи, пошто су долазили на такозвани „вечерњи акт“. Она га са тог првог сусрета описује као тамнопутог младића, коврџаве косе и јаких белих зуба, који је у том тренутку био прилично бучан. Постали су добри другови, посебно после смрти њиховог заједничког пријатеља Милана Штајнера. Њихов однос ће се касније и даље развијати али никада неће бити до краја разјашњен. Чињеница је да је Антонију портретисао и насликао за њу цвеће у крчагу за четкице, а веома је извесно да му је била и мотивација за акт. Чињеница је да је и „Голгота“ посвећена Антонији Кошчевић, што такође говори у прилог сложености њиховог односа. Сматра се да његова мајка Персида није одобравала ту везу. Антонија Кошчевић је била католкиња, Хрватица, имала је дете и била пет година старија од њега. Све су то могли бити више него довољни разлози жени патријархалног васпитања и провинцијског окружења да се супротстави тој вези. Антонија у Шумановићевој мајци види кривца за непријатности које ће му се касније дешавати и према њој гаји одређену нетрпељивост. Сава Шумановић је насликао портрет Антоније Кошчевић, познат као „Портрет госпођице T“. Портрет је урађен хладним тоновима зелене и црне боје са неколико налета јарке црвене боје, приказан је скоро класицистичким поступком. ${ }^{17}$ На „Акту девојке“ лик подсећа на Антонију приказану с леђа у контрапосту. ${ }^{18}$

Важан моменат у Шумановићевом животу било је дружење са младим песником Антуном Бранком Шимићем. Шимић је био писац, критичар, преводилац, уредник неколико часописа који су били кратког века. Њих двојица су имали много тога заједничког, пре свега били су носиоци иноваторских тежњи у Загребу после Првог светског рата. Шумановић је урадио насловне стране за Шимићев часопис

\footnotetext{
${ }^{16} \mathrm{O}$ томе сведочи Антонија Кошчевић у „Балади о покојном школском другу Сави Шумановићу“. D. Bašičević, наведено дело, 214.

${ }^{17}$ Класицистички поступак - тежња да се уметничка дела стварају по устаљеним правилима, на основу класичних узора.

${ }^{18}$ Контрапост - у ликовним уметностима то је начин држања тела, где сва тежина почива на једној нози, док је друга лагано повијена, чест је у грчкој класици а преузела га је и ренесанса.
} 
„Јуриш“ и за Шимићеве песме „Преображења“. Шумановић је у духу радозналости и трагањем у оквиру разних ликовних области урадио техником суве игле две добре графике „Матошева улица“ и „Вестибил“ где се може приметити дух конструктивног експресионизма. У том духу урадио је и две литографије, ${ }^{19}$ од којих је једну „Улица“ поклонио Народном музеју. Бавио се и сценографијом у Хрватском народном казалишту, па је тако у мају 1920. године осмислио сценографије за Моцартову оперу „Дон Ђовани“ у режији Иве Рачића, и за Ибзенову драму која није изведена. Временом је увидео да сценографски рад може лоше утицати на његово сликарство, па је убрзо изгубио интерес за сценографију.

Непрекидно се образовао, говорио немачки и француски језик, читао дела Волтера и Анатола Франса, али и лаку литературу у оригиналу, највише романе са садржајима из 18. века, читао књиге о уметности такође у оригиналном издању. Његова самостална изложба у Загребу у Музеју за умјетност и умјетни обрт доживела је како је говорио „леп морални и материјални успех.“20 Већи број тих радова откупио је загребачки трговац Гривичић, а многима се касније изгубио траг. Критика је о изложби писала углавном позитивно. О изложби су писали К.Хаусер у „Критици“, Г. Крклец у „Ријеци“, В. Јурковић у „Народној политици“итд. ${ }^{21}$ Осетио је снажну подршку критике, што му је импоновало и дало му снагу за даље напредовање „Критика ме метнула у ред првих сликара света и ја сам био окружен доста великом љубазношћу и пажњом.“22 Материјални успех изложбе му је омогућио одлазак у Париз али и утицао на његове родитеље да му редовно шаљу новац. У септембру 1920. године, носећи свој таленат и добро савладан сликарски занат, упутио се ка центру уметничких дешавања.

У Паризу (1920-1921) је радио много, био је под великим утицајем Андре Лота, познатог теоретичара и уметничког педагога. Имао је неприлике од самог почетка, није добио трајну визу нити право да своје слике продаје и излаже. Тежак положај у Француској натерао га је да се врати у Загреб. Загреб је у време Шумановићевог повратка био пун уметничких дешавања. Водећи југословенски уметници су излагали своја дела, која су у себи носила нешто авангардно. Такође су почели да излазе многи уметнички листови, који су имали позитиван став према новим тенденцијама у уметности. Те 1921. године Мирослав Крлежа пише: „Маргиналије“ 23 уз слике Петра Добровића а појављује се и Зенитистички манифест. Зенитизам је био пре свега књижевни правац после Првог светског рата, југословенска варијанта експресионизма присутна у Шимићевим и Крлежиним делима. Група се окупљала око часописа „Зенит“. ${ }^{24}$

\footnotetext{
19 Литографије - графичка техника исцртавања литографског камена (плоче)и прављења отиска на папиру.

${ }^{20}$ С. Шумановић, Каталог изложбе 1939, Нови универзитет, Београд 1939, 9.

${ }^{21} \mathrm{D}$. Bašičević, наведено дело, 10.

${ }^{22}$ С. Шумановић, Каталог изложбе1939, Нови универзитет, Београд 1939, 10.

${ }^{23}$ Маргиналије- белешке исписане на маргинама текста, успутне белешке, примедбе и размишљања у вези с оним што се чита, цртежи којима аутор илуструје свој текст.

${ }^{24}$ „Зенит“ - часопис који је излазио најпре у Загребу, а затим у Београду од 1921-1926. године са ознаком „интернационална ревија за уметност и културу“. Часопис је уређивао Љубомир Мицић, а у њему су
} 
Када се у лето 1921. године вратио у Загреб, Шумановић је становао код Антоније Кошчевић у Гундулићевој 50, на другом спрату. У Загребу је 1921. године први пут пописано становништво, Загреб је имао више од сто хиљада становника. Шумановић је изложио у првој половини новембра 1921. године у Умјетничком павиљону, своје париске и најновије загребачке радове. Приказао је педесет једно уље, четири акварела, једанаест цртежа и четири скице. Свестан да доноси нешто ново, страховао је да не дође до неспоразума између њега и посматрача његових дела. У предговору каталога изложбе је написао „Слика се рађа интуитивно из доживљаја који је код сликара ритмичан и пластичан, ${ }^{25}$ дакле сасвим визуелан никако дескриптиван. Сама та интуиција и доживљај нису још слика, већ је то само подлога, на којој ће тек настати слика. Најважније је сад код тога, да ли сликар слику импровизира, тј. да ли сликар слика слику само покоравајући се своме примарном чувству или је фактично ствара доносећи законе и ред у своју слику. Првим начином не долази се никада до једног објективног дела, створеног за вечност, већ само до констатовања свога доживљаја, тј. до једне неорганизоване експресије, која има такођер својих великих лепота, а другим путем конструктивним, објективним, где је само први подстицај настао из доживљаја, а остали рад је само стварање према вечним и безграничним законима, долази се до синтетичног дела.“ 26

Обзиром да је са изложбе продат само један акварел, може се и са те стране говорити о неуспеху изложбе. Шумановића је очигледно погодила несхваћеност његових слика од стране широке публике и појединих критичара. Замерали су му да се на сликама превише осећа Париз, школа, Пикасо, Сезан и други, а да би било боље када би се он вратио пређашњем стилу. Поводом неугодне полемике између Саве Шумановића и Бранимира Ливадића, ${ }^{27}$ у хумористичком часопису „Покрет“ из децембра 1922. године, карикатурално је приказан „Бој Саве Шумановића и Бранимира Ливадића“ уз стихове:

$$
\begin{gathered}
\text { „Ударио јунак на јунака } \\
\text { Шумановић на Ливадић Бранка } \\
\text { Од Сљемена до шидскога бријеста } \\
\text { Бој културни никако не преста } \\
\text { А Матош их са Парнаса прати } \\
\text { Па их мири: „Ем смо сви Хрвати“ } 28
\end{gathered}
$$

Постојали су и критичари чији су судови о Шумановићевој изложби били веома повољни. Главни браниоци његовог сликарства у том периоду су били А.Б Шимић и Растко Петровић. ${ }^{29}$

\footnotetext{
сарађивали и Милош Црњански, Растко Петровић, Станислав Винавер, Драган Алексић и други писци, окупљени око групе „Алфа-београдска литерарна заједница“

${ }^{25}$ Пластичан - ствара верну, живу слику нечега, живописан, рељефан, складан, хармоничан.

${ }^{26}$ Сава Шумановић, Каталог изложбе из новембра 1921, Музеј савремене уметности, Београд 1984, 64.

${ }^{27}$ Бранимир Ливадић- главни уредник часописа „Савременик“.

${ }^{28}$ D. Bašičević, наведено дело, 203.
} 
Шимић у есеју „Конструктивно сликарство“З30 побија замерке академске и нестручне критике па између осталог каже да сликарство не треба и не може бити чисто имитативно, доказ су и друге уметности од којих се не тражи то што већина тражи од сликарства. Сматра да на слици природа мора бити трансформисана или апстрахована по одређеним законима који ће у овај нови свет унети ред. ${ }^{31}$

Растко Петровић у есеју „Сава Шумановић и естетика сувише стварног у новој уметности“ говори како Шумановић избацује из себе чврсте и снажне конструкције, чвршће него стене. Подржава праву и дубоку естетику коју је прихватио Шумановић и наговештава да је то пут у нови реализам којим ће поћи и сва европска уметност. ${ }^{32}$

Шумановић је о изложби из 1921. године много година касније рекао: „Када сам дошао натраг у Загреб публика је била запрепашћена тим сликама, а критика није смела да пише од страха пред непознатим.“ж33

У Прилазу број 49 пронашао је стан који му је служио и као атеље, остао је у њему све време боравка у Загребу. У периоду од 1922. до 1925. године мало је сликао, свега око двадесетак слика. Већину тих слика потписивао је француском транскрипцијом, јер је био уверен да ће их ускоро изложити у Паризу, али и због политичких трзавица код нас. Учествовао је у многобројним полемикама, пропагирајући модерну француску уметност, које су се одвијале у кафани у позоришту, кафани „Бауер“ у Франкопанској улици, али и у његовом атељеу. У том периоду је настао и један од ретких Шумановићев цртежа, на коме се налазе три мушкарца за кафанским столом од којих је један био његов земљак Витомир Кораћ. ${ }^{34}$ На основу тога се може закључити да је обраћао пажњу на тренутно актуелне политичке личности. Боравећи у Загребу у више наврата је имао прилику

\footnotetext{
${ }^{29}$ Растко Петровић - песник, романописац, есејиста, путописац и дипломата, један од најзначајнијих представника српске авангардне књижевности. Родио се у Београду а у Паризу је завршио студије права. Као седамнаестогодишњак учествовао је у повлачењу српске војске преко Албаније у Првом светском рату. Он је млађи брат сликарке Надежде Петровић а његово познанство са Шумановићем је све више прерастало у блиско пријатељство.

${ }^{30}$ Конструктивно сликарство- сликарски правац који у свом изразу, лишеном декорације и субјективне емотивности, наглашава елементе конструкције и геометријске апстракције. Геометријска композициона шема почиње да избија на површину сликарског платна а облик и линија као основни градивни елементи на слици почињу да избијају у први план. Сава Шумановић у Паризу прихвата те идеје дајући им свој печат.

${ }^{31}$ Antun Branko Šimić, Konstruktivno slikarstvo, Savremenik 3, Zagreb 1921, 184-185.

${ }^{32}$ Rastko Petrović, Sava Šumanović i estetika suviše stvarnog u novoj umetnosti,Savremenik 3, Zagreb 1921, 183-184.

${ }^{33}$ С. Шумановић, Каталог изложбе 1939, Нови универзитет, Београд 1939, 11.

${ }^{34}$ Витомир Кораћ рођен је у Шиду, али је једно време боравио у Београду, где је упознао Васу Пелагића и прихватио социјалистичке идеје. Повезао се са Социјалистичком странком у Загребу и био изабран за члана главног одбора Социјалистичке странке Хрватске и Славоније. Више пута је хапшен због свог политичког деловања. Првобитно је социјалистичке идеје ширио међу пријатељима и познаницима, а од јануара 1908. године по Шиду и околини је почео одржавати јавне зборове. Те године на изборима у Шидском котару је однео убедљиву победу као кандидат Социјалдемократске странке. Постао је тако посланик у Хрватском сабору и ушао у историју као први и једини посланик социјалиста у Хрватској и Славонији.
} 
да се увери у нарастајући хрватски национализам, који је био опште познат и испољен у тежњама Хрвата ка самосталној административној јединици, оспоравању централизма и династије Карађорђевић, а све то преко званичних ставова појединих хрватских политичких странака. Пратило га је од самог доласка у Загреб увек актуелно и увек сложено питање српско-хрватских односа. Био је увек свестан своје националне припадности, дружећи се у Загребу са Хрватима често је долазило до безазлених шала на националној основи.

Сава Шумановић је био члан „Прољетног салона“ па је тако био чест и запажен излагач. Учествовао је на Петој југословенској изложби са четири слике. Сећајући се те изложбе рекао је: „За време женидбених свечаности покојног Краља Александра 1922. године држава је приредила целокупну југословенску изложбу, свих школа и свих праваца, а ја сам суделовао у групи „независних уметника“ (који су били прави незавишњаци, а не као који си данас то име присвајају па излажу уз жирије) која није познавала жирија. У тој групи били су Петар Палавичини, Сибе Миличић, Бијелић и друга господа па и ја, који сам био заступљен на тој изложби са четири слике, од којих су „Берба“, „Француско село“ и „Крај са мостом“ биле продане за доста велику своту, те сам постигао највећу продају на изложби (...)“35 Министарство просвете је откупило „Бербу“ и „Крај с мостом“. Приредио је изложбу у јануару 1922. године у салону Антона Улриха. Изложба није успела по броју продатих слика али није изазвала тако жесток удар на његово стваралаштво као прва изложба по повратку из Париза.

На очево инсистирање да уђе у неку државну службу како би му била осигурана егзистенција, упутио је молбу Министарству просвете да добије место хонорарног наставника цртања у Уметничкој школи у Београду. Одговор никада није добио али се уз помоћ пријатеља запослио у Загребу као помоћни учитељ основне школе и као музејски библиотекар.

Занимљиво је да је Сава Шумановић по повратку из Париза у Загреб, насликао портет Милоша Црњанског, који је тада, био професор у Београду и изузетно добро познавао сликарство. Црњански је био велики заговорник експресионизма. По повратку у Загреб довршио је и слику „Морнар на молу“ која више спада у оквир његових радова из претходне године. Његово стваралаштво од 1923. до 1925. године могло би се назвати неокласицистичким, али пошто је тај неокласицистички приступ био геометријски подвучен, може се назвати подфазом конструктивизма. Значајнија дела тог типа су: „Пасторала“, „Варијације из античке средине“, „Жена крај прозора“, „Концерт у пољу“ итд. ${ }^{36}$ У делима тог типа склоност ка општем је изражена у избору идеалних грчко-римских хероизираних ликова, често датих из профила а његова аутономна схваћеност слика често је изражена преко односа целине и делова, својства облика, линије, боје. На појединим сликама је уочљива изразита експресионистичка енергија. ${ }^{37}$

\footnotetext{
${ }^{35}$ С. Шумановић, Каталог изложбе 1939, Нови унливерзитет, Београд 1939,11.

${ }^{36} \mathrm{D}$. Bašičević, наведено дело, 50.

${ }^{37}$ Миодраг Б. Протић, Сава Шумановић, Шид 1985, 52-55.
} 
Сава Шумановић је 1924. године објавио у часопису „Књижевник“ текстове: „Сликар о сликарству“ и „Зашто волим Пусеново сликарство“. У првом тексту објављеном у мају покушава да открије особине и разлоге чистог сликарства. Занимљиво је како он објашњава на примеру модерног аутомобила и кочије из времена Луја XIV, однос према савршеним достигнућима различитих епоха. Кочију Луја XIV сматра изузетном али у времену Луја XIV, она за њега може представљати само вредан музејски експонат а никако нешто чиме би било прикладно обављати дневне послове. Његов однос према „старим кочијама“ свакако се може протумачити као однос према унапред постављеним уметничким и цивилизацијским законитостима прошлости. ${ }^{38}$

Изузетно добро је познавао историју уметности и носиоце најзначајнијих уметничких струјања, али је сматрао да дух новог времена сме и мора да пробије уметничке оквире и давно постављене стваралачке законитости, који не смеју бити прихваћени као неоспорне догме.

У другом тексту објављеном у јуну, на примеру Николе Пусена, образлаже сликарске вредности Николе Пусена које је и сам истински веома ценио. Огорчен је на подржавање кича и патетике у уметности и на стимулисање по њему безначајних вредности у уметности. У тексту између осталог каже: „Код нас се воли лажна патетика, имитација природе, илустративно сликање, шаренило колорита, јер имамо таке мозгове да волимо оно што је најбезначајније и што нам си чини мистериозно. Ми не осећамо мистериј хармоничног дела, али када видимо какову илустративну кошмарију или кад видимо пејзаж са зеленом травом ( којему би се волови врло веселили да имају мало смисла за сликарство), игра наша пургерска душица од весеља. Кушао сам да се од свега тога ослободим, и волим тога уметника, који је знао да организује своје осећаје, и стварао дела тврда, схематична и окамењена, јер је следио ону мисао коју је написао у писму М. де Шантелуу: „Настојаћу из свих снага да задовољим уметност, Вас и себе“.“”39

Последње слике његовог неокласицистичког низа настају 1925. године, када се својим „Аутопортретом“ поново враћа реалном и најављује окретање боји. Та година, иначе последња година његовог боравка у Паризу, донела му је тежак емотивни ударац због смрти његовог пријатеља Шимића. Антонија Кошчевић је касније говорила о томе како је легао на отоман и заплакао, када је чуо вест о смрти пријатеља. Исте године десило се и нешто што му је омогућило поновни одлазак у Париз. Адвокат Дорић се заинтересовао за Шумановићеве слике и купио двадесет слика. Све то је омекшало и Шумановићевог оца који је обећао да ће му и он финансијски помагати током боравка у Паризу. Занимљиво је да је он током боравка у Загребу, иако физички удаљен од Париза, излагао слике у париским салонима, Јесењем салону и Салону независних. Многи критичари су тако помињали његово име и пре његовог повратка у Париз, а један холандски

\footnotetext{
${ }^{38}$ Sava Šumanović, Slikar o slikarstvu, Književnik 1, Zagreb 1924, 20-24.

${ }^{39}$ Sava Šumanović, Zašto volim Pusenovo slikarstvo, Književnik 2, Zagreb 1924, 57-59.
} 
колекциионар је издвојио велику своту новца за Шумановићеву слику „Мртва природа“.

Сава Шумановић, храбро стремећи ка новим уметничким трагањима, поново одлази у Париз где ће остати до 1928. када ће се због болести вратити у Шид код родитеља.

\section{Извори и литература:}

Извори:

Документарна грађа Галерије слика „Сава Шумановић“ у Шиду.

Тубић, Цветанка, сведочење (пензионерка из Шида која је познавала Саву Шумановића)

Шумановић, Сава, Каталог изложбе из новембра 1921, Музеј савремене уметности, Београд 1984.

Шумановић, Сава, Каталог изложбе 1939, Нови универзитет, Београд 1939.

Периодика:

Petrović, Rastko, Sava Šumanović i estetika suviše stvarnog u novoj umetnosti, Savremenik 3, Zagreb 1921.

Šimić, Antun Branko, Konstruktivno slikarstvo, Savremenik 3, Zagreb 1921.

Šumanović, Sava, Slikar o slikarstvu, Književnik 1, Zagreb 1924.

Šumanović, Sava, Zašto volim Pusenovo slikarstvo, Književnik 2, Zagreb 1924.

Литература:

Bašičević, Dimitrije, Sava Šumanović.Život i delo, Novi Sad 1997.

Миљковић, Љубица, Сава Шумановић. Препуштање пасији, Београд 2007.

Протић, Миодраг Б., Сава Шумановић, Шид 1985.

Фајфрић, Жељко, Шид од оснивања до 1914. године, Шид 2003.

Horvat, Josip, Politička povijest Hrvatske, Zagreb 1936.

Črnja, Zvane, Kulturna historija Hrvatske. ideje-ličnosti-dela, Zagreb 1965.

Šišić, Ferdo, Pregled povijesti hrvatskoga naroda, Zagreb 1962. 


\title{
ZAGREB PERIOD IN THE PAINTINGS OF SAVA ŠUMANOVIĆ FROM 1914 TO 1925
}

\begin{abstract}
Summary
The paper deals with the historical context of paintings of Sava Šumanović during his stay in Zagreb, the then Zagreb cultural scene, holders of avant-garde tendencies in art, which supported Šumanović, as well as with the resistance provided to new artistic trends. The paper explains Šumanović's struggle for modern ideas of the constructive art. It also deals with the important moments Šumanović's personal life, his relationship with parents and Antonia Koščević, and his close circle of friends. The paper indirectly reflects on the complex issue of the Serbo-Croatian relations.
\end{abstract}

Keywords: Sava Šumanović, Zagreb period, Zagreb cultural scene, constructive painting, Antonija Koščević, Serbo-Croatian relations 